study of past casualties. For example, our data indicate that a programme of preventing heroin use in the 1990s will be ineffective if it focuses on injecting: initiation into heroin use is now by chasing, and the progression (or non-progression) to injecting occurs at a later stage through influences of which we know little.

We are grateful to the Department of Health for research grant support. The views expressed are those of the authors.
1 Parker H, Newcombe R, Bakx K. The new heroin users: prevalence and characteristics in Wirral, Merseyside. Br f Addiction 1987;82:147-58. 2 Gossop M, Griffiths P, Strang J. Chasing the dragon: characteristics of heroi chasers. Br $\mathcal{F}$ Addiction 1988;83:1159-62.

3 Bewley TH, Connell PH, Chapple PAL, Owens J. Centres for treatment of drug addiction. $B M F$ 1967;ii:498-502.

4 Home Office. Statistical bulletin on the misuse of drugs: 1990. London: HMSO 1991.

5 Brettle RP, Bisset K, Burns S, Davidson J, Davison SJ, Gray JMN, et al. Human immunodeficiency virus and drug misuse: the Edinburgh experience. BMF 1987;295:421-4.

(Accepted 18 February 1992)

\title{
Urinary 5-hydroxyindole acetate concentration in pregnancy induced hypertension
}

\author{
G Marcus Filshie, Paul Maynard, Christopher \\ Hutter, Jason C Cooper, Graham Robinson, \\ Peter Rubin
}

\section{University Hospital,}

Queen's Medical Centre,

Nottingham NG7 2UH

$\mathrm{G}$ Marcus Filshie, reader and consultant in obstetrics and gynaecology

Paul Maynard, lecturer in reproductive biochemistry Christopher Hutter, consultant anaesthetist Jason C Cooper, senior house officer in obstetrics and gynaecology

Graham Robinson, senior lecturer, department of pathology

Peter Rubin, professor of therapeutics

Correspondence to: $\mathrm{Dr}$ Filshie.

$B M \mathcal{F} 1992 ; 304: 1223$
The role of pressor agents, and particularly serotonin in the pathogenesis of pregnancy induced hypertension has been proposed. Abnormal circulating concentrations of serotonin have not been detected, ${ }^{2}$ but serotonin concentrations in platelets of pre-eclamptic women are reduced. ${ }^{3}$ A recent report of the successful treatment of an eclamptic patient with widespread cerebral ischaemia with nimodipine, ${ }^{+}$a potential inhibitor of serotonin, promised further study. Twenty four hour specimens of urine from patients with pregnancy induced hypertension and controls were analysed.

\section{Patients, methods, and results}

The study involved 13 women with pregnancy induced hypertension recruited from the antenatal ward over two weeks and 19 control patients of similar gestation: All but one patient had proteinuria as determined by an Albustix reagent strip. However, only five patients had proteinuria greater than $500 \mathrm{mg} /$ $24 \mathrm{~h}$ collection. In these five cases the proteinuria ranged from 0.65 to $3.64 \mathrm{~g} / 24 \mathrm{~h}$ with a mean of $2.01 \mathrm{~g} / 24 \mathrm{~h}$. The clinical details are shown in the table. None of the patients with pregnancy induced hypertension were receiving treatment at the time of analysis.

Patients had a 24 hour specimen of urine collected into a bottle containing hydrochloric acid, which was frozen until analysed. The concentrations of 5-hydroxyindole acetate, a urinary metabolite of serotonin, was measured by gas chromatography and mass spectrometry without knowledge of subject group.

Clinical and laboratory details of subjects studied

\begin{tabular}{|c|c|c|c|c|c|}
\hline & \multicolumn{2}{|c|}{ Normotensive group $(\mathrm{n}=19)$} & \multicolumn{2}{|c|}{ Hypertensive group $(n=13)$} & \multirow{2}{*}{$\begin{array}{l}\text { (Mann-Whitney } \\
\text { U test) }\end{array}$} \\
\hline & Median & Range & Median & Range & \\
\hline $\begin{array}{l}\text { Total } 24 \text { hour urine } \\
\text { volume (1) }\end{array}$ & 1.43 & $0 \cdot 56-2 \cdot 9$ & 1.06 & $0.62-1.56$ & NS \\
\hline $\begin{array}{l}\text { Gestational age at time of } \\
\text { sampling (weeks) }\end{array}$ & 33 & $29-39$ & 37 & $30-39$ & NS \\
\hline Maternal age (years) & 26 & $18-31$ & 28 & $19-36$ & NS \\
\hline $\begin{array}{l}\text { Systolic blood pressure } \\
(\mathrm{mm} \mathrm{Hg})\end{array}$ & 120 & $100-130$ & 150 & $140-177$ & \\
\hline $\begin{array}{l}\text { Diastolic blood pressure } \\
\text { (mm Hg) } \\
\text { 5-Hydroxyindole acetate }\end{array}$ & 70 & $60-80$ & 100 & $88-114$ & \\
\hline $\begin{array}{l}\text { concentration }(\mu \mathrm{mol} / \mathrm{l}) \\
\text { Total } 24 \text { hour excretion of }\end{array}$ & $18 \cdot 0$ & $8 \cdot 5-51 \cdot 1$ & $30 \cdot 6$ & $17 \cdot 9-44 \cdot 6$ & $<0.001$ \\
\hline $\begin{array}{l}\text { 5-hydroxyindole acetate } \\
(\mu \mathrm{mol})\end{array}$ & $25 \cdot 9$ & $13 \cdot 1-44 \cdot 5$ & $30 \cdot 7$ & $25 \cdot 3-49 \cdot 9$ & $<0.005$ \\
\hline $\begin{array}{l}\text { 5-Hydroxyindole acetate: } \\
\text { creatinine }(\mu \mathrm{mol} / \mathrm{g}) \\
\text { No of primiparous women }\end{array}$ & $\begin{array}{r}21 \cdot 8 \\
4\end{array}$ & $14 \cdot 1-32 \cdot 5$ & $\begin{array}{r}23 \cdot 6 \\
9\end{array}$ & $20 \cdot 0-45 \cdot 4$ & $<0.05$ \\
\hline No of multiparous women & 15 & & 4 & & \\
\hline
\end{tabular}

Results between the two groups were compared by the Mann-Whitney U test. Urinary excretion of 5-hydroxyindole acetate was significantly greater in the patients with pregnancy induced hypertension than in the controls (table). The difference was most marked for absolute concentrations, but was also apparent for excretion rate and concentration in relation to creatinine. There was no significant difference between the proteinuric hypertensive patients and the nonproteinuric hypertensive patients when comparing the 24 hour total urinary output of 5-hydroxyindole acetate or the $\mu \mathrm{mol} / \mathrm{g}$ of creatinine ratio.

\section{Comment}

Serotonin is a neurotransmitter and is also found in platelets, being released into the circulation during the platelet release reaction. It is extensively metabolised, 5-hydroxyindole acetic acid being the major metabolite. We have found substantially more 5-hydroxyindole acetate in the urine of women with pregnancy induced hypertension than in normotensive controls of similar gestation. A possible contributory factor to this could be related to the significant increase in embolic trophoblastic fragments found in the venous circulation of women with pregnancy induced hypertension compared with non-hypertensive controls. ${ }^{5}$ The trophoblastic fragments could attract platelets which in turn could release platelet serotonin. This trophoblastic factor is unique to pregnancy.

It is likely that the increased urinary excretion of 5 hydroxyindole acetate reflects increased circulating concentrations of serotonin, possibly related to trophoblastic fragmentation, which is significantly increased in women with pregnancy induced hypertension. Though this assumption contrasts with an earlier report, ${ }^{2}$ it is doubtful if the methodologies used in previous studies were of sufficient sensitivity. We would also propose that the increased circulating serotonin is derived from platelets which have undergone aggregation as part of the pre-eclamptic process. Our observations were made when hypertension was already established and we cannot therefore draw inferences about the possible contribution of serotonin to the initiation of the pre-eclamptic process. However, we suggest that increased circulating concentrations of serotonin could contribute to at least some of the features of pre-eclampsia or eclampsia. In particular, serotonin alone or in combination with other vasoconstrictor agents could contribute to the cerebral vasospasm which seems to be a feature of eclampia. ${ }^{4}$

1 Weiner CP. The role of serotonin in the genesis of hypertension in pre eclampsia. Br f Obstet Gynaecol 1987;156:885-8.

2 Jelen I, Fananapazie L, Crawford TBB. The possible relationship between late pregnancy, hypertension and 5-hydroxytryptamine levels in maternal blood. pregnancy, hypertension and 5-hydr

3 Whigham KAE, Howie PW, Drummond AH, Prentice CRM. Abnormal platelet function in pre-eclampsia. Brf Obstet Gynaecol 1978;85:28-32.

4 Horn EH, Filshie GM, Kerslake RW, Jaspan T, Worthington BS, Rubin P. Widespread cerebral ischaemia treated with nimodipine in a patient with eclampsia. BMF 1990;301:794.

5 Jaammeri KEU, Koivuniemi AP, Carpen EO. Occurrence of trophoblasts in the blood of toxaemic patients. Gynaecologia 1965;160:315-20. 